\title{
Comparative evaluation of DNA integrity using sperm chromatin structure assay and Sperm- Ovis-Halomax during in vitro capacitation of cryopreserved ram spermatozoa
}

Patricia Peris-Frau, Manuel Alvarez-Rodriguez, Alicia Martin-Maestro, Maria IniestaCuerda, Irene Sanchez-Ajofrin, Jose Julian Garde, Heriberto Rodriguez-Martinez and Ana Josefa Soler

The self-archived postprint version of this journal article is available at Linköping University Institutional Repository (DiVA):

http://urn.kb.se/resolve?urn=urn:nbn:se:liu:diva-161618

N.B.: When citing this work, cite the original publication.

Peris-Frau, P., Alvarez-Rodriguez, M., Martin-Maestro, A., Iniesta-Cuerda, M., Sanchez-Ajofrin, I., Julian Garde, J., Rodriguez-Martinez, H., Josefa Soler, A., (2019), Comparative evaluation of DNA integrity using sperm chromatin structure assay and Sperm-Ovis-Halomax during in vitro capacitation of cryopreserved ram spermatozoa, Reproduction in domestic animals, 54, 46-49.

https://doi.org/10.1111/rda.13519

Original publication available at:

https://doi.org/10.1111/rda.13519

Copyright: Wiley (12 months)

http://eu.wiley.com/WileyCDA/ 
Comparative evaluation of DNA integrity using Sperm Chromatin Structure Assay and Sperm-Ovis-Halomax during in vitro capacitation of cryopreserved ram spermatozoa

P. Peris-Frau ${ }^{1}$, M. Álvarez-Rodríguez ${ }^{2}$, A. Martín-Maestro ${ }^{1}$, M. Iniesta-Cuerda ${ }^{1}$, I. Sánchez-Ajofrín $^{1}$, J.J. Garde ${ }^{1}$, H. Rodriguez-Martinez ${ }^{2}$, A.J. Soler ${ }^{1}$ ${ }^{1}$ SaBio IREC (CSIC-UCLM-JCCM), Albacete, Spain.

${ }^{2}$ Department of Clinical and Experimental Medicine, Faculty of Medicine and Health Sciences, Linköping University, Linköping, Sweden.

\section{CONTENT}

This work aimed to compare the ability of Sperm Chromatin Structure Assay (SCSA ${ }^{\circledR}$ ) and Sperm-Ovis-Halomax ${ }^{\circledR}$ to detect DNA fragmentation in frozen-thawed ram sperm incubated under capacitating conditions in synthetic oviductal fluid (SOF) supplemented with estrous sheep serum (SOF-ESS) at multiple time points (0-240 min). Incubation in SOF-ESS had no significant effects on $\mathrm{SCSA}^{\circledR}$ parameters while the percentage of spermatozoa with fragmented DNA measured by Sperm-Ovis-Halomax ${ }^{\circledR}$ increased after 180 min of incubation. In addition, no correlation or agreement was found between the techniques suggesting that $\mathrm{SCSA}^{\circledR}$ and Sperm-Ovis-Halomax ${ }^{\circledR}$ may quantify different types of DNA damage in ovine spermatozoa under these experimental conditions.

Keywords: Sperm capacitation, DNA integrity, $\mathrm{SCSA}^{\circledR}$, Sperm-Ovis-Halomax ${ }^{\circledR}$, ovine

\section{INTRODUCTION}


Several techniques have been applied to detect DNA damage. The $\operatorname{SCSA}^{\circledR}$ has been tested and contrasted in different species showing high repeatability and sensitivity (Evenson et al., 2002). Although this powerful method offers the possibility to analyze thousands of sperm cells per minute by flow cytometry, it involves an expensive equipment and skilled operators, requiring the use of proper standard samples for the initial adjustment. In contrast, the $\operatorname{Halomax}^{\circledR}$ kit, which is a variation of the sperm chromatin dispersion test, only requires a light or fluorescence microscope, being timeconsuming but more affordable and easier to carry out. Moreover, it has been optimized for diverse mammalian species (Gosálvez et al., 2011).

Both techniques have been employed to estimate DNA fragmentation in ram spermatozoa (López-Fernández et al., 2008; Martinez-Pastor et al., 2004), however, to the best of our knowledge, comparative studies between these two assays have not been performed in this species.

Cryopreservation, long incubation periods, the composition of media and the use of sperm selection procedures during in vitro fertilization may all adversely affect sperm DNA integrity (Gürler et al., 2016; Peris et al., 2004). To determine whether the DNA stability of ram spermatozoa is compromised by any of these factors; spermatozoa were selected after cryopreservation, by centrifugation through a single layer of colloid (Percoll $45 \%$ ) and then, incubated for $240 \mathrm{~min}$ in capacitating conditions. The aim of the present work was to elucidate if SCSA ${ }^{\circledR}$ and Sperm-Ovis-Halomax ${ }^{\circledR}$ provide similar information on ram sperm DNA fragmentation under the experimental above-mentioned conditions.

\section{MATERIALS AND METHODS}

\subsection{Animal ethics and chemicals}


Animal handling was conducted in agreement with Spanish Animal Protection Regulation, RD 96 53/2013. All chemicals were acquired from Sigma-Aldrich (Sweden), with the exception of the Sperm-Ovis-Halomax ${ }^{\circledR}$ kit (Hallotech DNA S.L., Madrid, Spain) and Biladyl ${ }^{\circledR}$ (Minitube, Tiefenbach, Germany).

\subsection{Sperm collection, cryopreservation and in vitro capacitation}

Semen was collected via artificial vagina from four different Manchega rams ( $>3$ years) provided by the Regional Center of Animal Selection and Reproduction (CERSYRA, Valdepeñas, Spain) at regular intervals of one per week. All pools of semen $(n=3,12$ ejaculates) were diluted to $200 \times 10^{6} \mathrm{sperm} / \mathrm{ml}$ in Biladyl ${ }^{\circledR}$ with $20 \%$ egg yolk and frozen in $0.25 \mathrm{ml}$ straws following the protocol described by García-Álvarez et al. (2009). Frozen-thawed spermatozoa were subjected to centrifugation through a single column of Percoll 45\%. The sperm pellet was resuspended in synthetic oviductal fluid (SOF) supplemented with $10 \%$ of estrous sheep serum (ESS) (SOF-ESS; capacitating medium) or SOF supplemented with $0.1 \%$ polyvinyl alcohol (PVA) (SOF-PVA; negative control) to a final concentration of $10 \times 10^{6} \mathrm{sperm} / \mathrm{ml}$. Spermatozoa suspended in SOF-ESS were incubated for $240 \mathrm{~min}$ at $38.5^{\circ} \mathrm{C}$ under $5 \% \mathrm{CO}_{2}$. DNA integrity was assessed at $0 \mathrm{~min}$ in SOF-PVA and at 1, 5, 15, 30, 60, 120, 180 and $240 \mathrm{~min}$ in SOF-ESS.

\subsection{The sperm chromatin structure assay $\left(\mathrm{SCSA}^{\circledR}\right)$}

The SCSA ${ }^{\circledR}$ is based on the susceptibility of sperm with normal or impaired DNA to acidinduced denaturation, which can be quantified by flow cytometry using the metachromatic properties of acridine orange (AO). SCSA ${ }^{\circledR}$ was performed by triplicate following the protocol described by Evenson et al. (2002). Briefly, samples diluted to $2 \mathrm{x}$ $10^{6}$ cells/ml with TNE buffer were thawed and mixed with $400 \mu 1$ of an acid-detergent solution. After 30 seconds, $1.2 \mathrm{ml}$ of $\mathrm{AO}$ was added and the stained samples were evaluated 3 min later in a Gallios ${ }^{\mathrm{TM}}$ flow cytometer (Beckman Coulter, Bromma, 
Sweden). A total of 5,000 spermatozoa per sample were assessed. Flow cytometry data (FCS) were acquired by the Navios software (Beckman Coulter, Bromma, Sweden) and processed by Weasel v. 3.2 (WEHI, Melbourne, Australia). Further analysis of FCS using R software (package rflowcyt - Bioconductor) were performed to obtain the percentage of DNA fragmentation index (DFI, \%).

\subsection{The Sperm-Ovis-Halomax ${ }^{\circledR}$}

This technique relies on the response of unfragmented or fragmented sperm DNA to a protein depletion treatment, by lysis. Samples were processed by triplicate according to the manufacturer's instructions (Hallotech DNA S.L., Madrid, Spain). Liquefied agarose was mixed with sperm samples at $37{ }^{\circ} \mathrm{C}$. A drop of each mixture was placed on pretreated slide and covered with a coverslip. The slides were stored at $4{ }^{\circ} \mathrm{C}$ for $5 \mathrm{~min}$ and the coverslips were subsequently removed. Immediately, slides were fully immersed in lysis solution at room temperature. After $5 \mathrm{~min}$, the slides were washed in distilled water and sequentially dehydrated in ethanol. Finally, dry slides were stained with $1 \mu 1$ of propidium iodide mounted with $1 \mu 1$ of antifading under a coverslip. Spermatozoa were visualized in an epi-fluorescence microscope (Eclipse 80i, Nikon, Tokyo, Japan) and 300 cells per sample were counted. Spermatozoa with unfragmented DNA showed a small or null halo of dispersed chromatin, while spermatozoa with fragmented DNA showed a large halo, representing the sperm DNA Fragmentation index (sDFI, \%).

\subsection{Statistical analysis}

Statistical analyses were performed with SPSS v. 23.0 (IMB corp., Chicago, USA). After data normalization by square root transformation, the effect of sperm capacitation on DNA integrity over time was evaluated using a general linear model (GLM) followed by the Bonferroni post hoc test. Values were expressed as means \pm SEM. To estimate the relationship and the level of agreement between the $\mathrm{SCSA}^{\circledR}$ and Sperm-Ovis-Halomax ${ }^{\circledR}$ 
the Pearson correlation coefficient and the intra class correlation coefficient (ICC) were used respectively. Significance was set at $\mathrm{P}<0.05$.

\section{RESULTS}

The percentage of DFI $\left(\mathrm{SCSA}^{\circledR}\right)$ and sDFI (Sperm-Ovis-Halomax $\left.{ }^{\circledR}\right)$ over the incubation period is depicted in Fig. 1, denoting that the assessed spermatozoa had low proportions of DNA fragmentation (below $7.53 \% \pm 0.38 \%$ ). As it can be seen, $\mathrm{SCSA}^{\circledR}$ showed the lowest values $(2.43 \% \pm 0.64 \%)$ compared to Sperm-Ovis-Halomax ${ }^{\circledR}(5.66 \% \pm 0.93 \%)$. Changes in the percentage of sDFI detected by the Sperm-Ovis-Halomax ${ }^{\circledR}$ kit were dependent on incubation time and media, being DNA fragmentation higher after $180 \mathrm{~min}$ of incubation $\left(\mathrm{P}<0.05\right.$; Fig. 1). However, the DFI proportions measured by the SCSA ${ }^{\circledR}$ did not show any significant difference throughout the entire incubation period $(\mathrm{P}>0.05)$ (Fig. 1). Correlations between sDFI and DFI were not found $(\mathrm{P}>0.05)$. Finally, the ICC revealed a poor agreement $(\mathrm{ICC}=0.133 ; \mathrm{P}>0.05)$ among the results obtained with both methods.

\section{DISCUSSION}

$\mathrm{SCSA}^{\circledR}$ and Sperm-Ovis-Halomax ${ }^{\circledR}$ were used to investigate changes in DNA status in ram spermatozoa stressed by cryopreservation, selected through centrifugation in a Percoll column and further incubated for 240 min under capacitation conditions. Despite these experimental conditions, only spermatozoa measured by Sperm-Ovis-Halomax ${ }^{\circledR}$ showed significant differences in DNA fragmentation regarding to the negative control by the end of incubation period. Apparently, Sperm-Ovis-Halomax ${ }^{\circledR}$ seems to be more discriminative than $\mathrm{SCSA}^{\circledR}$ but these data must be interpreted cautiously since both techniques differ methodologically.

SCSA $^{\circledR}$ detects abnormalities in double-stranded DNA conformation after spermatozoa are exposed for 30 seconds to acid-detergent solution, allowing DNA 
denaturation only at the sites of single- or double-strand breaks (Evenson et al., 2002). Sperm-Ovis-Halomax ${ }^{\circledR}$ can, on the other hand, simultaneously evaluate disturbances in nuclear proteins and DNA (De La Torre et al., 2007) . This method applies a reducing agent together with a lysis solution instead of an acid-detergent to break disulphydryl bonds and remove partially nuclear proteins, creating nucleoids with halos of DNA loops. Therefore, it is plausible that SCSA ${ }^{\circledR}$ can provide different information on DNA damage that Halomax ${ }^{\circledR}$.

Both techniques also differ in the number of spermatozoa tested. Whereas the SCSA ${ }^{\circledR}$ run a screening of 5,000 events/spermatozoa per sample using a flow cytometer, the Sperm-Ovis-Halomax ${ }^{\circledR}$ only manually checked 300 spermatozoa per sample.

Previous studies did not find any correlation (García-Macías et al., 2007) or agreement (Ortiz et al., 2017) between $\operatorname{SCSA}^{\circledR}$ and Halomax ${ }^{\circledR}$, which is in accordance with our results. While the sDFI was apparently affected by long incubations, the DFI did not change over time. This might mean that prolonged incubations during capacitation do not alter sperm DNA in ram. However, considering that the proportion of affected spermatozoa between the techniques differed over $2 \%$ throughout the entire incubation, less subjective measurements must be done for Sperm-Ovis-Halomax ${ }^{\circledR}$. Future studies should include image digitization and the use of an automatic counting software for Sperm-Ovis-Halomax ${ }^{\circledR}$ as López-Fernández et al. (2008) reported.

In summary, the proportion of DNA fragmentation in ram spermatozoa was low in both techniques, even considering the stressful experimental conditions of this study for the cryopreserved spermatozoa. The output data (sDFI vs DFI) differed probably because SCSA $^{\circledR}$ and Sperm-Ovis-Halomax ${ }^{\circledR}$ detect different types of chromatin damage, but the differences in measured sperm numbers and the type of accounting can be blurring the 
nature of the differences. This comparison clearly suggests there is a need for further studies.

\section{ACKNOWLEDGEMENTS}

PPF was supported by a University of Castilla-La Mancha scholarship. The study was supported by grants from ALF-Research (Region Östergötland, LIO-698951), FORSS (Forskningsrådet i Sydöstra Sverige, Grant 473121 and Grant 745971), Lions Forskningsfond (DNR LIU-2016-00641) Linköping and the Swedish Research Council Formas (grant 2017-00946), Stockholm Sweden. Samples were evaluated in the Department of Clinical and Experimental Medicine from the Faculty of Medicine and Health Sciences in Linköping, Sweden.

\section{CONFLICT OF INTEREST}

The authors declare that there is no conflict of interest.

\section{REFERENCES}

De La Torre, J., López-Fernández, C., Pita, M., Fernández, J. L., Johnston, S. D., \& Gosálvez, J. (2007). Simultaneous observation of DNA fragmentation and protein loss in the boar spermatozoon following application of the sperm chromatin dispersion (SCD) test. Journal of Andrology, 28(4), 533-540. https://doi.org/10.2164/jandrol.106.002246

Evenson, D. P., Larson, K. L., \& Jost, L. K. (2002). Sperm Chromatin Structure Assay: Its Clinical Use for Detecting Sperm DNA Fragmentation in Male Infertility and Comparisons With Other Techniques. Journal of Andrology, 23(1), 25-43. https://doi.org/10.1002/j.1939-4640.2002.tb02599.x

García-Álvarez, O., Maroto-Morales, A., Martínez-Pastor, F., Garde, J. J., Ramón, M., Fernández-Santos, M. R., ... Soler, A. J. (2009). Sperm characteristics and in vitro fertilization ability of thawed spermatozoa from Black Manchega ram: 
Electroejaculation and postmortem collection. Theriogenology, 72(2), 160-168. https://doi.org/10.1016/j.theriogenology.2009.02.002

García-Macías, V., De Paz, P., Martinez-Pastor, F., Álvarez, M., Gomes-Alves, S., Bernardo, J., ... Anel, L. (2007). DNA fragmentation assessment by flow cytometry and Sperm-Bos-Halomax (bright-field microscopy and fluorescence microscopy) in bull sperm. International Journal of Andrology, 30(2), 88-98. https://doi.org/10.1111/j.1365-2605.2006.00723.x

Gosálvez, J., López-Fernández, C., Fernández, J. L., Gouraud, A., \& Holt, W. V.

(2011). Relationships Between the Dynamics of Iatrogenic DNA Damage and Genomic Design in Mammalian Spermatozoa From Eleven Species. Molecular Reproduction and Development, 78(78), 951-961.

https://doi.org/10.1002/mrd.21394

Gürler, H., Malama, E., Heppelmann, M., Calisici, O., Leiding, C., Kastelic, J. P., \& Bollwein, H. (2016). Effects of cryopreservation on sperm viability, synthesis of reactive oxygen species, and DNA damage of bovine sperm. Theriogenology, 86(2), 562-571. https://doi.org/10.1016/j.theriogenology.2016.02.007

López-Fernández, C., Fernández, J. L., Gosálbez, A., Arroyo, F., Vázquez, J. M., Holt, W. V., \& Gosálvez, J. (2008). Dynamics of sperm DNA fragmentation in domestic animals. III. Ram. Theriogenology, 70(6), 898-908. https://doi.org/10.1016/j.theriogenology.2008.04.055

Martinez-Pastor, F., Johannisson, A., Gil, J., Kaabi, M., Anel, L., Paz, P., \& RodriguezMartinez, H. (2004). Use of chromatin stability assay , mitochondrial stain JC-1, and fluorometric assessment of plasma membrane to evaluate frozen-thawed ram semen. Animal Reproduction Science, 84, 121-133. https://doi.org/10.1016/j.anireprosci.2003.12.006 
Ortiz, I., Urbano, M., Dorado, J., Morrell, J. M., Al-Essawe, E., Johannisson, A., \& Hidalgo, M. (2017). Comparison of DNA fragmentation of frozen-thawed epididymal sperm of dogs using Sperm Chromatin Structure Analysis and Sperm Chromatin Dispersion test. Animal Reproduction Science, 187(September), 74-78. https://doi.org/10.1016/j.anireprosci.2017.10.007

Peris, S. I., Morrier, A., Dufour, M., \& Bailey, J. L. (2004). Cryopreservation of Ram Semen Facilitates Sperm DNA Damage: Relationship between Sperm Andrological Parameters and the Sperm Chromatin Structure Assay. Journal of Andrology, 25(2), 224-233. https://doi.org/10.1002/j.1939-4640.2004.tb02782.x

Fig. 1 Sperm DNA fragmentation (\%) obtained by Sperm-Ovis-Halomax ${ }^{\circledR}$ (sDFI) and Sperm Chromatin Structure Assay (DFI) at 0 min in a negative control (SOF-PVA) and after incubation of frozen-thawed ram sperm in a capacitating medium (SOF-ESS). Letters (a-c) illustrate significant differences during incubation period in both media $(\mathrm{P}<$ $0.05)$. Values are means \pm SEM. 


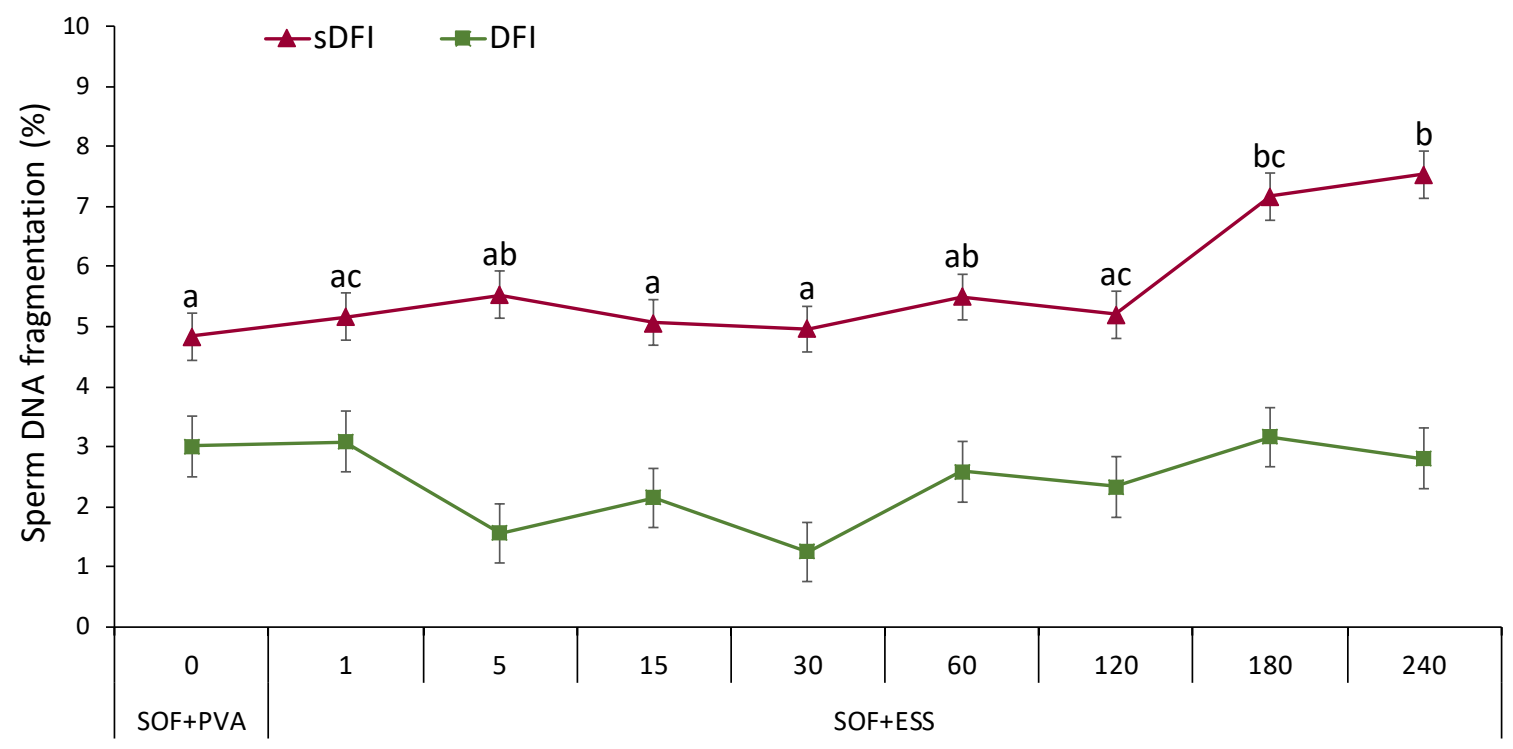

Time (min) 